\title{
The Mystery of Vladimir Nabokov
}

Aza Petrovna Tikhonova

\author{
Susanna Rashidovna Makerova
}

Svetlana Aleksandrovna Sasina

Ekaterina Nikolaevna Orekhova

Zaineta Ruslanovna Khachmafova

Adyghe State University

Email: aza.tihonova@mail.ru

Doi:10.5901/mjss.2015.v6n3s4p115

Abstract

The analysis of the novel Lolita by Vladimir Nabokov (English and Russian versions) has revealed the peculiarities of the novel on the level of contents and the plot and on the lexical level. The results of the analysis make it possible to come to the conclusion that the novel is a multilevel structure, inherently Russian in culture in spite of the abundance of French words and the English context. As to its communicative organization, it is an implied dialogue between the author and the reader, it is a double-voiced discourse that serves the author and the narrator at the same time to expresses simultaneously two different intentions. Nevertheless, in spite of its Russian imprint, the novel may be considered a unique phenomenon of world culture. There is no doubt that the work of true bilinguals, to which the great Russian-American writer V.V. Nabokov, deserves special attention in view of combining ethnic and cultural codes and harmonious combination of different ethno-psycholinguistic rules of each language (Karabulatova \& Polivara, 2013).

Keywords: introspective observations, idiosyncrasy, self-translation, superimpose, the cultural competence.

\section{Introduction}

Vladimir Nabokov enjoys love of so many researchers that it would take pages and pages to enumerate all of them. Nevertheless, a lot of questions remain unanswered. For understanding V. Nabokov and his novels it is vitally important to answer the question whether he is still a Russian writer in his English novels or American of Russian descent, as some researchers put it, or Cosmopolitan. The present article we'll help us to give, if not exhaustive, at least some definite answer to this question. As rightly emphasizes I.S. Karabulatova, "we see that the complexity of the process of cultural texts (which is most characteristic of the culture of the European type) has the character of entropy at observed primitivization forms, the abundance of a variety of" remakes ", typing motifs and images. Virtualization consciousness, provoking introvertiveness character development of the world, contributes to the design of new virtual cultural spaces with its internal logic and perception system para-reality, specific cultural codes and identification codes, their history and mythology" (Karabulatova, 2013, p. 794).

\section{Objectives and Tasks of Research}

This article is devoted to those characters that usually remain in the shade of the novel and nevertheless they are visibly present on every page of V. Nabokov's novel: they are the omniscient author who goes in and out of people's thoughts and the reader. They present not less interest than the characters of the novel themselves. In the article we'll try to clear out the relations of the author with his main characters and the anonymous character of his novels known under the name «my dear reader».

\section{Material and Methods}

The material of investigation is limited to V. Nabokov's novel Lolita (English and Russian versions). The method of 
investigation is very simple. We'll compare the text of the two versions of the novel Lolita with the facts of V. Nabokov's biography. We'll also take into consideration what $\mathrm{V}$. Nabokov says about himself in his lectures and reviews. We'll also use the most reliable, in our opinion, works by B. Boyd. In our investigation we come from the presumption that the idiosyncrasy of the personality of the writer is rendered in the text irrespective of his will. In this difficult situation polyaspectualic recipient interprets statements based on knowledge of the world, prisoners in the representations, and fill the necessary logical connections and draw conclusions in order to understand a speaker and / or writer (Karabulatova, Sayfulina \& Vasilishina, 2013).

Our investigation strategy is based on the examination of implicit and explicit introspective observations of the writer and their reflexes in his works (Stein, 2003). In his «Lecture on Russian Literature» V. Nabokov underlines that any speech activities are complicated inevitably by the elements of the personal characteristics of the producer of the speech (Nabokov, 1999). In A. Kovtun's opinion, text for V. Nabokov is a kind of code that is supposed to be decoded by the reader (Kovtun, 2001) and the quality of decoding, we presume, depends wholly on the talent of the reader.

\section{Russian Trace in the Novel Lolita}

By comparing the Russian and English versions of V. Nabokov's novel Lolita we can easily see that they are different, and this difference, first of all, depends to a great extent on «the dear reader», with whom the author shares his most cherished wishes and ideas and to whose best feelings he appeals for support and understanding, like: "I want my learned reader to participate in the scene I am about to replay» "I hope I am addressing myself to unbiased readers» (Nabokov, Lolita ...).

Through his fictional author Humbert V. Nabokov addresses the reader with such words as «my learned reader», "an avid reader», «the astute reader».

In his «Lectures on Literature» Vladimir Nabokov underlined the importance of a good reader "The good reader is my brother, my double" (Nabokov, 2002).

Why did V. Nabokov make a self-translation of the novel into Russian? Why did he not trust this work to a translator? He did it for a very simple reason. He realized that these versions will be read by readers of different cultures. The cultural competence of the reader reinscribes the translated text, superimposing a new layer of meaning (Treciak, 2009). The notions clear to a Russian reader will escape understanding of an English reader and vice versa. This is the reason why in his English version V. Nabokov uses the term "a middle class bourgeois» and in Russian «мещанин» (meçanin), which denotes a social group of petty bourgeoisie in Old Russia before the Revolution of 1917. Even now he word «мещанин» sounds like music to the ears of old Russians and their descendants (who are not wholly unaware of their origins). The Russian exclamation «царствие небесное добряку» expressing the last wish to the deceased to find peace in the Garden of Eden is adopted in the Russian Orthodox Church but is alien to English. So «God bless the good man» and «царствие небесное добряку» are not the exact equivalents. It is just enough to compare Humbert Humbert's addresses to the reader and to Lolita in English and Russian to make sure that they are culturally oriented. «My darling» and «my sweetheart» have the exact Russian equivalents «моя дорогая» and «моя милая» but the author prefers to use «душенька» (dushen'ka) and «голубка» (golubka). Instead of the English «folks» he uses "судари мои» which are typical of Russian culture. The use of the word «nanupoca» for the English «cigarette, the phrase «cmaрая ехидна», «старая дурында» for the English «old cat», "свинюги» for the English «good swine», "Geyziha» (the word with the Russian derogatory feminine suffix -ha) for the English «that Haze woman» and "Karmensitochka» for the English «my little Carmen» reflect the peculiarities of the Russian language and culture. "Синица в руке» (an allusion to the Russian proverb лучше синица в руке, чем журавль в небе = a bird in the hand is worth two in the bush) is not the exact equivalent for the English «business in hand» coined by V. Nabokov. "Бить баклуши» = to thimble one's thumbs is also a fact of Russian culture. But what surprises the reader of the English version of the novel is the awareness of the main character of the novel Humbert Humbert of the Russian morals and manners, the Russian language and Russian history. Humbert Humbert, a Swiss citizen of mixed French and Austrian descent, which is proved by the abundant use of French and modest use of German words of the type «die Kleine» «bruder» as address to the reader, "Fräulein von Kulp», "streng verboten». "sicher ist sicher», uses freely in his speech such notions of the Russian culture as «brainless bаbа» «безмозглая баба» (a brainless woman). The Russian diminutive suffix -chka in the name Valechka from Valeria and the surname Taksovich formed from «taxi-driver», the profession of Humbert Humbert's rival and lover of his wife, do not say much to the English reader who has no idea of the niceties of the Russian language. Moreover, Humbert Humbert's judgement on the Russian national habits makes us suggest either some Russian blood in his veins or at least a long stay in Russia: «I noticed with a spasm of fierce disgust that the former Counsellor of the Tsar, after thoroughly easing his bladder, had not flushed the toilet. That solemn pool of alien urine with a soggy, tawny cigarette butt 
disintegrating in it struck me as a crowning insult, and I wildly looked around for a weapon. Actually I dare say it was nothing but middle-class Russian courtesy (with an Oriental tang, perhaps) that had prompted the good colonel (Maximovich! his name had suddenly taxies back to me), a very formal person as they all are, to muffle his private need in decorous silence so as not to underscore the small size of his host's domicile with the rush of a gross cascade on top of his own hushed trickle» (Nabokov, Lolita ...).

\section{Two Authors, Two Readers in the Novel Lolita}

What puzzles English reader even more is a close liaison between the narrator of the novel Humbert Humbert and the author himself. The autobiography of Humbert Humbert is unexplainably interlaced with the biography of V. Nabokov. The utterances cited below belong, no doubt, to Humbert Humbert: «At first, I planned to take degree in psychiatry as many manqué talents do, but I was even more manqué than that; a peculiar exhaustion, I am so oppressed, doctor, set in; and I switched to English literature, where so many frustrated poets end as pipe-smoking teachers in tweeds. Paris suited me» [V. Nabokov. Lolita]. But the next phrase belongs unmistakably to V. Nabokov himself. It's an admitted fact of his biography: «l discussed Soviet films with expatriates» (Nabokov, Lolita ...).

Our arguments about the author and the reader would be incomplete if we ignored the fact that the novel Lolita is made up of layers of doublings, created by the real author. There are two authors and two readers in the novel, which are completely different and worship different views. Trying to shed some light on the problem we'll proceed from Bakhtin's notion of a discourse as a dialogue and from the notion of heteroglossia. So, any text for us is a dialogue between the author and the reader and heteroglossia is the expression of authorial intentions in a refracted way. A double-voiced discourse serves two speakers at the same time and expresses simultaneously two different intentions: the direct intention of the character who is speaking and the refracted intention of the author. In such a discourse there are two voices, two meanings and two expressions. And all the while these two voices are dialogically interrelated (Bakhtin, 1981). Appel notes "There are...at least two plots in all of Nabokov's fiction: the characters in the book, and the consciousness of the creator above it" (Appel 1991, xxvi).

Vladimir Nabokov attaches such a great importance to a good reader that in his Lectures on Literature he calls him "my brother, my double" (Nabokov, 1999).

The real author in Lolita seeks encouragement from the unbiased reader: «Mid-twentieth-century ideas concerning child-parent relationship have been considerably tainted by the scholastic rigmarole and standardized symbols of the psycho-analytic racket, but I hope I am addressing myself to unbiased readers» (Nabokov, Lolita ...).

The fictional author Humbert Humbert, trying to save if not his head then his soul, addresses more often to the jury than to a common reader. In fact, he writes his story for the court trial: «Gentlemen of the jury! I cannot swear that certain emotions pertaining to the business in hand ... had not thrilled me. Frigid gentlewomen of the jury! I had thought that months, perhaps years, would elapse before I dared to reveal myself to Dolores Haze; but by six o'clock she was quite awake, and by 6.15 we were technically lovers. I am going to tell you something very strange. It was she who seduced me» (Nabokov, Lolita ...).

The surname of the narrator and the main character of the novel Lolita Humbert Humbert may be interpreted in two ways. If we proceed from the French word «ombre» (shadow) and its Spanish homonym «hombre» (man) the doubling of the name may be understood as "the shadow of man» since the main character has already been dead by the moment of publication of this novel. At the same time Humbert Humbert, as any other narrator of V. Nabokov's novels, may be interpreted as «the shadow of the author himself» (Nabokov, 2004). The author ascribes to him his own occupations and hobbies. Like V. Nabokov, the main character is a specialist in literature and teaches English in one of American Universities ("I started to compile that manual of French literature for English-speaking students (with comparison drawn from English writers)... I found a job - teaching English to a group of students in Auteuil. I was urged by a wartime university in New York to compel my comparative history of French literature for English-speaking students» (Nabokov, Lolita ...)). His hobby is chess. Humbert played chess games with a polish doctor and plays chess with the teacher Gaston Godin three times weekly. Like V. Nabokov, Humbert Humbert is multilingual: he speaks English, German and French. But he is a representative of a Francophone rather than Anglophone culture. According to Humbert Humbert, he speaks horrible careful English. The text of the novel is rich in French utterances which together with already described traces of the Russian culture present difficulties for the English reader. The subject of the novel only aggravates difficulties for the reader in understanding the text. The narrator and the main character of the novel Jean-Jacque Humbert is a sexual pervert (pedophile) with love for pubescent girls under 12. He is a person with a split personality. He lives in an ambiguous world where the subconscious reigns and there is no place for conscious mind. The novel looks like a manual in sexual pathology, describing all the symptoms of pedophilia in details. Speaking about details, we may 
refer to V. Nabokov himself who in his Lectures on Literature more than once underlined the importance of details (Nabokov, 1999). We must not forget that V. Nabokov is a successful scientist in entomology (lepidoptera: butterflies, in particular) and investigations in this field require details.

Being a shadow of the real author, Humbert Humbert, in his turn, has a shadow of his own, his double Claire Quilty.

This character is the most uncomprehended mystery of the novel. He is an invisible man. For the first time he appears on the pages of the novel as a playwright, Dr Quilty's uncle or cousin. We don't see him, we only hear his name («We have an excellent dentist. Our neighbour, in fact. Dr. Quilty. Uncle or cousin, I think, of the playwright» (Nabokov, Lolita ...)). Next time we hear about Quilty's involvement into an indecent story: «Last time he told me a completely indecent story about his nephew» (Nabokov, Lolita ...). Later we hear from Lolita that there is someone in the dining room who looks like Quilty. But we don't see him - «Does not he look exactly, but exactly like Quilty? - Like our Ramsdale dentist? - Course not, I meant the writer fellow in the Dromes ad» (Nabokov, Lolita ...). In the long run Humbert Humbert's double becomes visible: For the first time he appears only in the second part of the novel (chapter 18) as man from the Aztec Red Convertible, his «red shadow», as he puts it, who pursues Humbert Humbert and Lolita. The appearance of his pursuer coincides with electrical disturbance and crepitating lightnings when Humbert Humbert, a man with split personality, has hallucinations. Suppose his «red shadow» is creation of his fevered imagination.

«... anyhow it would have been too foolish even for a lunatic to suppose another Humbert was avidly following Humbert and Humbert's nymphet with Jovian fireworks, over the great and ugly plains» (Nabokov, Lolita ...).

Later he appears as man without a face: «white-glistening in the rain-dripping darkness, there stood a man holding before his face the mask of Jutting Chin, a grotesque sleuth in the funnies» (Nabokov, Lolita ...). Next time Humbert Humbert sees him through a side window of his car: «A broad-backed man, baldish, in an oatmeal coat and dark-brown trousers» (Nabokov, Lolita ...). Humbert Humbert doesn't know even his name and sees him only from afar on the lake and on the tennis court: «I saw him scratch his cheek and nod, and turn and walk back to his convertible, a broad and thickish man of my age, somewhat resembling Gustave Trapp, a cousin of my father's in Switzeland - same smoothly tanned face, fuller than mine, with a small dark moustache and rosebud degenerate mouth»; «He (Lolita's partner) had a remarkably round head and wore incongruous brown trousers» (Nabokov, Lolita ...). He learns his name nearly at the end of the novel from Lolita. Quilty turns out to be an old friend of Dolly's mother, Cue by name. He materializes himself only at the end of the novel. So, the rightful question arises, whether he exists in reality and is not an invention of a sick mind. Quilty is Humbert's evil and dark part. There is diabolic resemblance between them. They are men of the world, in everything - sex, free verse, marksmanship. Like Humbert, Quilty speaks French. Like Humbert, he wears a purple bathrobe. Humbert and Quilty fulfill completely the criteria of the classical doubles, like Stevenson's «Dr. Jekyll and Hyde» or Oscar Wilde's «Dorian and his Picture». By killing Quilty, Humbert Humbert signs himself a death sentence. Meanwhile, Quilty's role in the conflict of the novel is very great. By kidnapping Lolita he saves her from a pervert, a maniac who has deprived Lolita of her childhood declining in this way all responsibility for Humbert Humbert's sins and crimes. The scene of Quilty's murder is as unreal as the character himself, in the best traditions of American Westerns.

\section{Freud in the Novel Lolita}

Besides the problems of the mind and the body and aesthetic values, the novel is concerned with the theory of psychoanalysis underlying it.

It is assumed that V. Nabokov's old feud with Freud lies in his rejection of psychoanalysis as such. It is not exact, to a certain extent. He is against Freudian methods of psychoanalysis (Nabokov, 1990). His novel Lolita is permeated with psychoanalysis. Through his narrator Humbert Humbert V. Nabokov develops his own approach to psychoanalysis. According to Humbert Humbert, his original plan to take a degree in psychiatry has not come true. Nevertheless, his knowledge of psychiatry (if his words are to be trusted) allowed him to join an expedition to Arctic Canada as a «recorder of psychic reactions» who studies nostalgia, fear of unknown animals, food-fantasies, nocturnal emissions, hobbies, etc. Later he maintains close contacts with psychotherapists and social workers: «Despite my having dabbled in psychiatry and social work, I really knew very little about children». As a psychiatrist he characterizes adequately girls of puberty age. «Now I wish to introduce the following idea. Between the age of limits of nine and fourteen there occur maidens who, to certain bewitched travellers, twice or many times older than they, reveal their true nature which is nit human, but nymphic (that is demoniac); and these chosen creatures I propose to designate as nymphets». He accurately describes the conflict between individual desire and collective prohibition: While my body knew what it craved for, my mind rejected my body's every plea. One moment I was ashamed and frightened, another recklessly optimistic. Taboos strangled me. Psycho-analysts wooed me with pseudoliberations of pseudolibidoes (Nabokov, Lolita ...). All these facts affirm that the 
author is well read in this subject. In our opinion, Brian Boyd's assumption that V. Nabokov has read Freud's early writings on child sexual abuse in the library of his father, one of the leading Russian criminologists and a specialist in sexual crimes, is not groundless (Boyd, 1991). Such a sentence from the novel Lolita seems to prove it: I wish I might digress and tell you more of the pavor nocturnus (nightmares) that would rack me hideously after a chance term had struck me in the random readings of my boyhood, such as peine forte et dure (anguish) (what a Genius of Pain must have incented that) or the dreadful mysterious, insidious words 'trauma', 'traumatic event' and 'transom' (Nabokov, Lolita ...).

Though the name of Freud is not very frequent in the novel (neo-Freudian, the Freudian symbol, any good Freudian with a German name), he is invisibly present since the first pages. Trying to explain his obsession with twelve year-old girls Humbert Humbert looks for the origin of his sexual and mental woes in the distant childhood: in frustrated love for Annabel and her untimely death, which is in full compliance with Sigmund Freud who explains neuroses and phobias as stemming from childhood traumas (Breuer, 1909) (Lolita began with Annabel) In the novel Humbert Humbert produces dreams which, on the face of it, seem to prove Sigmund Freud's technique of psychoanalysis, his theory of wish fulfilment in a dream, in particular: «If I ever commit a serious murder... Mark the 'if'. Remember that only a spell of insanity could ever give me the simple energy to be a brute (all this amended, perhaps). Sometimes I attempt to kill in my dreams. But do you know what happens? For instance I hold a gun. For instance I aim at a bland, quietly interested enemy. Oh, I press the trigger all right, but one bullet after another feebly drops on the floor from the sheepish muzzle. In those dreams, my only thought is to conceal the fiasco from my foe, who is slowly growing annoyed» (Nabokov, Lolita ...). Later Humbert Humbert will fulfil his unrealized dream and will kill Clare Quilty, his rival in love for Lolita).

But further comments on dreams contain severe criticism of Freudian methods of diagnosis and interpretation of patient's dreams. Humbert Humbert mocks Freud's extortion of dreams from his patients: «I discovered there was an endless robust enjoyment in trifling with psychiatrists: cunningly leading them on; never letting them see that you know all the tricks of the trade; inventing for them elaborate dreams, pure classics in style (which make them, the dreamextortionists, dream and wake up shrieking); teasing them with fake 'primal scenes'; and never allowing them the slightest glimpse of one's real sexual predicament. By bribing nurse I won access to some files and discovered with glee, cards calling me 'potentially homosexual' and 'totally impotent'» (Nabokov, Lolita ...).

Compare this comment with V. Nabokov's interview to the National Educational Television network, the program, produced by Robert Hughes on Channel 13 Thursday from 9:30 to 10 P.M.

That is how he explains why he detests Dr. Freud: «I think he's crude, I think he's medieval, and I don't want an elderly gentleman from Vienna with an umbrella inflicting his dreams upon me. I don't have the dreams that he discusses in his books. I don't see umbrellas in my dreams. Or balloons» (Zimmer, 1994-2004).

Humbert Humbert shows that Freudians try to ascribe some sexual sense to any dream.

«I swallowed a sleeping pill, and presently a dream that was not a sequel but a parody revealed to me, with a kind of meaningful clarity, the lake I had never visited: it was glazed over with a sheet of emerald, and a pockmarked Eskimo was trying in vain to break it with a pickaxe, although imported mimosas and oleanders flowered on its gravely banks. I am sure Dr Blanche Schwarzmann would have paid me a sack of shillings for adding such a libidream to her files» (Nabokov, Lolita ...).

The next interpretation of Humbert Humbert's dream is an attack on Freudian preoccupation with decoding symbols:

"There it (the pistol) lay ready for instant service on the person or persons, loaded and fully cocked with the slide locked in safety position, thus precluding any accidental discharge. We must remember that a pistol is the Freudian symbol of the Urfather's central forelimb» (Nabokov, Lolita ...).

So we see that Nabokov's conflict with Freud is more serious than some researchers try to show (Shute, 1984). Unverifiability of Freud's predictions and diagnoses must have led V. Nabokov to the conclusion that Freud's theory is a pseudoscience, one of the vilest deceits, and in the hands of charlatans and amateurs it will become a dangerous weapon as it deals with generalizations and has recourse to universals and archetypes. The failure of Freud's psychoanalysis is clearly seen in his misinterpretation of Leonardo da Vinci's dream about a kite (Aleksandrov, 1995).

Another possible explanation of V. Nabokov's controversy with S. Freud lies, perhaps, in Russian culture. Freud's limited penetration into Russian culture may be explained by the incumbency of Russian Symbolism, a movement whose obsessions occupied a sphere similar to that of psychoanalytic discourse (Etkind, 1994). Considering the Russianlanguage the discourse of V. Nabokov, we found specific mental representations "Russia", "which are determined similarly named explication of the global semantic space prose writer (Basilishina, Karabulatova \& Zamaletdinov, 2013, p. 126).

The unconscious, a preoccupation with decoding symbols, and a world view meticulously constructed by 
systematic mythologizing are features shared by Freudian psychoanalytic thought and Russian Symbolism, but not prominent in the work of other psychologists and sexual theorists of the time (Etkind, 1994). So we come to the conclusion that V. Nabokov' conflict with S. Freud is the conflict of the West European and East European (Russian) cultures.

To comprehend the author's message «the dear reader» must be ready to keep all kinds of reference books and encyclopedia at hand because the novel looks like a kaleidoscope of special terms from Freudian theory: «primal scene» - a child's awareness of its parent's intercourse, «libidream» - the word derived from «libido» - sexual desire, pedophilia - sexual feelings directed toward children, sexual predicament - an embarrassed situation relating to instincts and physiological processes and activities connected with physical attraction or intimate physical contact between individuals, etc.

\section{Conclusion}

The analysis of the text of the novel Lolita has shown that it is a double-voiced discourse in the form of an implied dialogue between the author and the reader expressing simultaneously two different intentions, the direct intention of the narrator and the intention of the real author. There is no strict borderline between the author and the narrator. They very often overlap. Nevertheless, the author is visibly present in the novel and does not disappear as it happens in postmodern novels. The novel is made up of multiple layers of doublings, which keep the reader in suspense, and very often puzzle him. But the most pronounced feature of Nabokov's novel is blending of fiction and scientific treatise on sexual pathology. It results in critical assessment of psychoanalysis and Sigmund Freud. The text of the novel proves that Nabokov was well read in psychoanalysis already in green years and his conflict with Freud is rather a conflict of two cultures: West European (Freud) and East European (Russian) culture (Nabokov). The lexical and derivational layer of the text shows that the Russian culture has left an indelible imprint on his literary works and he remains essentially a Russian writer no matter what language he writes in. But his works is heritage not only of Russian but world culture as they tackle the problems common to all mankind.

\section{References}

Alexandrov, V. 1995. The Garland Companion to Vladimir Nabokov / Vladimir E. Alexandrov. - New York: Garland. pp. 412-20.

Appel, Alfred Jr. Foreword, 1991. The Annotated Lolita / Alfred Jr. Appel. New York: Vintage Books. pp. 460.

Bakhtin, Mikhail 1981. The dialogue. Orietntation of a Discourse / Mikhail Bakhtin. - Austin, TX: Unv. of Texas Press, 1981. pp. $186-187$.

Boyd, Brian \&Vladimir Nabokov 1991. The Russian Years / Brian Boyd. N.J., Princeton: Princeton University Press. pp. 607.

Breuer, Jos. Freud, Sigm. 1909. Studien über Hysterie / Jos. Breuer, Sigmund Freud. - Leipzig und Wien: Fr. Deuticke, pp. 26.

Etkind, A. 1994. Eros of the impossible. History of psychoanlysis in Russia. Moscow: Gnosis, Progress-Complex publishing house. pp. 384.

Karabulatova, I.S. 2013. The problems of linguistic modeling of new Eurasian linguistic personality in multilinguistic and mental environment (by example of onomasphere). In the: Middle-East Journal of Scientific Research 17 (6). pp. 791-795.

Karabulatova, I.S. \& Polivara Z.V. 2013. Turkic and Slavs: bi-polylinguism in globalization and migrations (on an example of Tumen region). In the: Middle-East Journal of Scientific Research 17 (6). pp. 832-836.

Kovtun, A. 2001. On the problem of Vladimir Nabokov's method in the essay «Lectures on Russian literature». St. Petersburg-Stavropol: SGU publishing house. pp. 545-549.

Nabokov, V.V. 2004. Foreword. Lolita. The Confession of a White Widowed Male. Moscow: AST publishing house. pp. 186.

Nabokov, V. 1999. Lectures on Russian literature. Moscow: Independent Newspaper publishing house. pp. 440.

Nabokov, V. 2002. Lectures on Literature / Vladimir Nabokov. - Boston: Mariner Books. pp. 385.

Nabokov, V. 1990. Strong Opinions / Vladimir Nabokov. - New York: Vintage. pp. 350.

Shute, Jenifer. Nabokov \& Freud 1984: The Play of Power / Modern Fiction Studies, Vol. 30. No. 4. pp. 637-50.

Stein, K.E. 2003. Language. Poetic text. Discourse. Pyatigorsk: PGLU publishing house. pp.: 6-13.

Treciak, Joanna 2009. Viennese Waltz: Freud in Nabokov's Despair / Comparative literature. Eugene, Oregon: University of Oregon. pp. 55-59.

Zimmer, Dieter E. Vladimir Nabokov: The Interviews 1994-2004 / Dieter E., Zimmer. Electronic resource. http://www.d-ezimmer.de/index.htm.

Vasilishina, E.N., Karabulatova I.S. \& Zamaletdinov R.R. 2013. On the problem of privative opposition in the mental representations of discourse implicature bilingual writer: geopolitonim "Russia" in the works of V. Nabokov. In the: Bulletin of Oryol State University. Series: New Studies in the Humanities, \#5(34), pp. 126-129.

Zamaletdinov, R.R., Karabulatova I.S., Sayfulina F.S. \& Vasilishina E.N. 2013. Linguistic and cultural aspect of the discourse implicature to blend space "character - a doll - puppet" (based on "synthetic" Nabokov's prose). In the: the: Bulletin of Oryol State University. Series: New Studies in the Humanities. \#5(34), pp. 134-138. 